\title{
Implementasi Metode Histerisis Kontrol Arus Untuk Pengaturan Kecepatan Dan Torsi Pada Motor De Chopper
}

\author{
Satrya Ramadhani, Johan Prasetyo, Firsyaldo Rizky P, M. Haidar Rosyid, Iradiratu Diah P.K \\ Program Studi Teknik Elektro, Fakultas Teknik dan Ilmu Kelautan, Universitas Hang Tuah Surabaya \\ Jalan Arief Rahman Hakim No. 150, Sukolilo, Surabaya 60111 \\ E-mail : satryaramadhani88@gmail.com, Johanprasetyo17@gmail.com, firsyaldo.rizky@gmail.com, haidarrsyd@gmail.com \\ untuk tegangan dc, dimana konverter ini dapat \\ Abstrak - Motor DC merupakan elemen mesin listrik yang \\ mempunyai fungsi pada dunia industri seperti pabrik kertas, \\ pabrik tekstil, penggulung tambang katrol dan digunakan \\ mengendalikan tegangan output dari alat tersebut (Mihai \\ Albu,2018). Pada prinsip pengontrol histerisis torsi pada \\ brushless motor $d c$
} juga sebagai motor servo untuk penentuan posisi dan pelacakan. Lambat laun penggunaan dari motor dc tersebut akan mengalami permasalahan juga. Permasalahan yang sering muncul pada pengaturan kecepatan motor dc yaitu kurangnya akurasi hasil referensi kecepatan yang diinginkan sehingga terjadi ketidak optimalan dalam pengoperasian di industri yang menggunakan elemen motor dc sebagai penggeraknya. Berdasarkan permasalahan tersebut maka dilakukan implementasi metode histerisis kontrol arus untuk menganalisa tingkat keakurasian dalam pengaturan kecepatan motor $d c$, dimana pada pengujian ini menggunakan nilai sampel beban dan torsi yang berbeda. Hasil pengujian yang sudah dilakukan menunjukan bahwa Voltage Source Converter (VSC) yang dirancang dalam penelitian ini telah bekerja dengan baik sesuai dengan tujuan pengguna. Hal ini dilihat dari grafik keluaran arus, tegangan, dan arus error menggunakan metode histerisis kontrol arus.

Kata Kunci - Motor DC, Histerisis, Voltage Source Converter, Simulink Matlab.

\section{Pendahuluan}

Motor DC atau motor arus searah merupakan elemen mesin listrik yang mempunyai fungsi pada dunia industri seperti pabrik rolling, pabrik kertas, penggulung tambang, katrol , peralatan mesin, traksi mesin cetak eksavator dan pabrik tekstil (Mahmood, O. T. 2018). Beberapa motor dc digunakan sebagai motor servo untuk penentuan posisi dan pelacakan (A.K. Mishra,

$V . K$, et al , 2013). Dengan meninjau dari segi fungsi dan kegunaan dari motor $d c$ maka diperlukan merancang pengaturan kecepatan motor $d c$ yang cocok sesuai kecepatan referensi yang dibutuhkan, agar nantinya dapat dioperasikan dengan optimal. Permasalahan yang sering muncul pada pengaturan kecepatan motor $d c$ chopper yaitu kurangnya akurasi hasil referensi kecepatan yang diinginkan sehingga terjadi ketidak optimalan dalam pengoperasian industri atau pabrik yang menggunakan elemen motor dc chopper sebagai penggeraknya.

Berdasarkan permasalahan yang sering terjadi pada motor dc chopper maka dapat dilakukan pengendalian kecepatan dengan mengatur arus jangkar atau arus medan (Esario et al, 2020) dan juga pengaturan arus dapat dilakukan dengan mengatur tegangan pada motor $d c$ chopper menggunakan konverter daya (Yakob Liklikwati, 2014). Pada penelitian ini diusulkan menggunakan $d c$ chooper 1 kuadran untuk mengatur kecepatan sebuah motor $d c$, yaitu sebuah peralatan konverter digunakan untuk memberikan perlindungan terhadap arus torsi dan juga mengontrol torsi secara dinamis yang andal dan cepat (Bahari, N. B, 2012).

Berdasarkan implementasi metode histerisis kontrol arus untuk pengaturan kecepatan dan torsi pada motor DC chopper yang digunakan sebagai prinsip pengontrol histerisis torsi (Bahari, N. B, 2012) maka pada penelitian ini akan pengembangan implemetasi pengaturan kecepatan menggunakan histerisis kontrol arus dengan variasi pembebanan sebagai sampel pengujian.

Hasil penelitian ini mampu untuk menganalisa tingkat keakurasian dalam pengaturan kecepatan motor dc chopper dengan mengunakan metode histerisis. Sehingga penelitian ini nantinya dapat dijadikan sebagai alternatif dalam metode pengaturan kecepatan motor $d c$ khususnya $D C$ chopper.

\section{BAHAN DAN METODE}

Pada penulisan ini dirancang sistem kontrol kecepatan motor DC menggunakan DC chopper satu kuadran yang diimplementasikan dengan metode hysterisis. Kecepatan motor DC dikontrol dengan cara mengatur arus jangkar. Selanjutnya arus jangkar dikendalikan dengan mengatur kecepatan dan torsi referensi pada motor DC chopper. Dalam penelitian ini dilakukan dengan bentuk permodelan sistem yang dimulai dari perancangan, pembuatan, dan pengujian menggunakan simulink matlab.

\section{Motor De Chopper}

Motor DC merupakan mesin yang mengubah energi listrik arus searah menjadi energi mekanis. Motor listrik berfungsi untuk mengubah daya listrik menjadi daya mekanik. Pada prinsip kerjanya, motor DC sangat identik dengan generator DC. Kenyataannya mesin yang bekerja sebagai generator DC akan dapat bekerja sebagai motor DC. Oleh karena itu, mesin arus searah dapat digunakan baik sebagai motor DC maupun generator DC (Rosalina 2017).

DC Chopper merupakan sebuah converter daya DC yang 
kecepatan dan torsi outputnya dapat dikendalikan, sehingga banyak digunakan untuk mengendalikan peralatan listrik yang menggunakan sumber tegangan DC. Dalam penulisan digunakan DC Chopper satu kuadran yang dapat beroperasi pada kuadran satu pada sistem kuadran (M. Ilham Esario 2020).

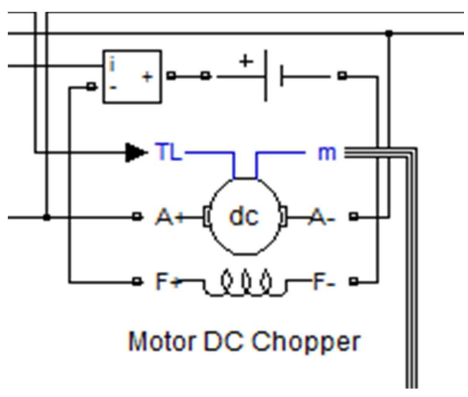

Gambar 1. Motor DC Chopper

\section{Voltage Source Converter (Vsc)}

VSC merupakan konverter yang menggunakan sumber tegangan dengan menyimpan energi yang berupa kapasitor. VSC dapat beroperasi pada beberapa model. Konverter yang menggunakan semikonduktor bidirectional dapat beroperasi dalam dua model, yaitu rectifier dan inverter. Dalam model penyearah, konverter akan merubah tegangan AC menjadi tegangan DC. Dalam model inverter, konverter akan merubah tegangan DC menjadi tegangan AC. Sehingga dapat dilakukan dengan menggunakan semikonduktor daya dua arah (bidirectional), seperti IGBT, sehingga arus dapat mengalir dua arah (Tri Yogi Putra 2020).

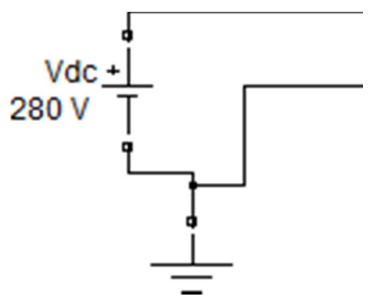

Gambar 2. Voltage Source Converter (VSC)

\section{Histerisis Kontrol Arus}

Untuk mengontrol nilai arus diperlukan output inverter agar dapat mengikuti referensi. Sinyal kontrol histerisis dengan menghitung selisih antara arus aktual outputan inveter yang dibaca oleh sensor dengan arus referensi yang berupa sinyal sinus, kemudian nilai arus error yang didapatkan dibandingkan dengan batas histerisis yang telah diatur (Ferry Aditya 2018).

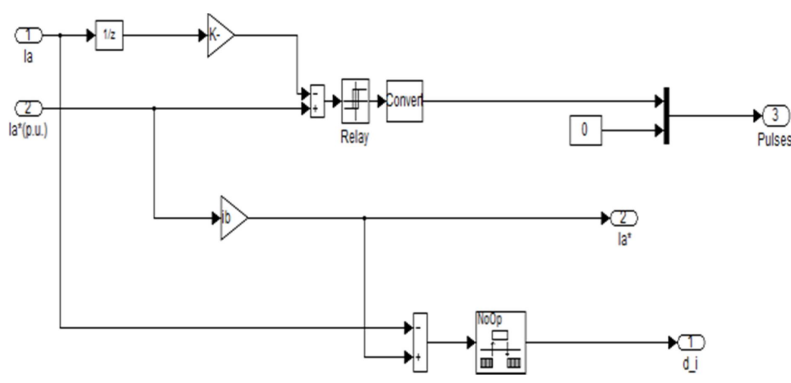

Gambar 3. Rangkaian Histerisis Kontrol Arus

\section{Speed Controller}

Pengaturan kecepatan dilakukan dengan beberapa cara, diantaranya dengan cara mengubah frekuensi. Pengaturan frekuensi untuk pengendalian motor DC chopper biasanya diikuti juga dengan pengaturan tegangan masuk yang sebanding dengan frekuensi tersebut. Dengan mempercepat dan memperlambat perioda putar motor DC, sehingga frekuensi dan kecepatan motor dapat diatur. Pengaturan kecepatan dengan cara ini sangat efesien dan daerah pengaturannya pun cukup luas.

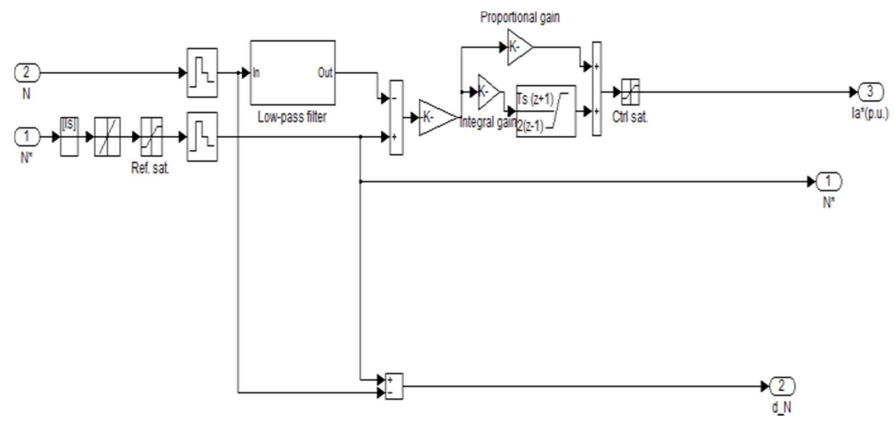

Gambar 4. Kontrol Kecepatan

\section{SENSOR ARUS}

Sensor arus yang ditentukan sebagai perangkat pengukuran dan pembacaan nilai arus yang melewati beban dalam perancangan penelitian ini. Sensor ini bekerja dengan prinsip half effect. Arus yang mengalir melalui sensor akan dibaca dan dikonversikan menjadi nilai tegangan yang tepat, sehingga sinyal berupa tegangan tersebut akan terbaca.

\section{SIMULINK MATLAB}

Simulink merupakan sebuah modul dari matlab yang bisa digunakan untuk mensimulasikan sistem dinamik dengan cara grafis berbentuk diagram blok, sistem tersebut dapat dimodelkan dengan diagram blok, panah sinyal, summing junction, blok gain, source dan sink. Pada dasarnya Simulink Matlab berfungsi untuk mendesain tampilan program dan memudahkan pengguna dalam pembuatan program sehingga tidak memerlukan penulisan kode untuk membuat tampilannya. 


\section{Hasil dan Pembahasan}

Gambar 5. Rangkaian implementasi metode histerisis kontrol arus untuk pengatur kecepatan dan torsi motor dc pada matlab simulik

Rangkaian Sistem Voltage Source Converter yang telah dibuat di ujikan ke pada beban Motor DC Chopper, yang dimana supply sumber diambil dari sumber DC yang dihubungkan dengan rangkaian sistem. Rangkaian sistem ini terdiri dari rangkaian catu daya, rangkaian gate drive/IGBT, sensor arus, dan motor DC chopper, kemudian nantinya akan di rancang pada simulink matlab. Setelah selesai membuat rangkaian sistem, selanjutnya dilakukan pengujian rangkaian. Untuk melihat grafik arus error, arus jangkar, arus tegangan, dan kecepatan motor DC chopper digunakan blok scope yang ada pada tools simulink matlab.

\section{A. Pengujian Rangkaian Sistem Pada Simulink Matlab}

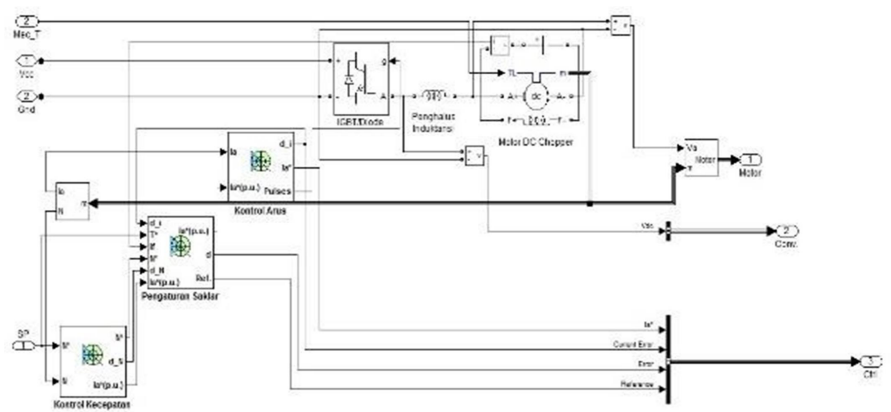

Gambar 6. Rangkaian Sistem Voltage Source Converter

Pada rangkaian sistem ini menggunakan catu daya 280 VDC Tegangan jangkar disuplai oleh konverter buck IGBT yang dikendalikan oleh dua regulator. Regulator pertama adalah pengatur kecepatan PI, diikuti oleh pengatur arus histeresis. Pengatur kecepatan mengeluarkan referensi arus jangkar (dalam p.u.) yang digunakan oleh pengontrol arus untuk mendapatkan torsi elektromagnetik yang diperlukan untuk mencapai kecepatan yang diinginkan. Laju perubahan referensi kecepatan mengikuti ramp akselerasi dan deselerasi untuk menghindari perubahan referensi mendadak yang dapat menyebabkan arus berlebih jangkar dan mengganggu kestabilan sistem.

Kontrol arus mengatur arus jangkar dengan mengirimkan pulsa yang benar ke perangkat IGBT untuk menjaga arus jangkar di dalam pita histeresis yang ditentukan oleh pengguna. Frekuensi switching perangkat IGBT dibatasi oleh induktansi penghalus motor dan induktansi eksternal yang ditempatkan secara seri dengan rangkaian jangkar.

\section{B. Pengujian 1 Kecepatan Motor DC 500-400 RPM Tanpa Beban}

Pada pengujian ini menggunakan parameter referensi ISSN 2615-5788 Print (2615-7764) JURNAL TEKNIK ELEKTRO DAN KOMPUTER TRIAC kecepatan dan torsi. Parameter tersebut digunakan untuk menentukan keluaran arus, tegangan, dan arus error pada

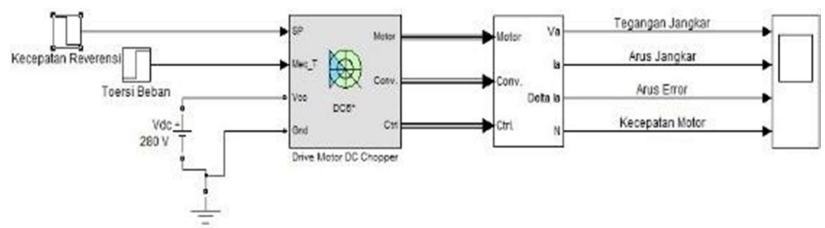

sisi jangkar.

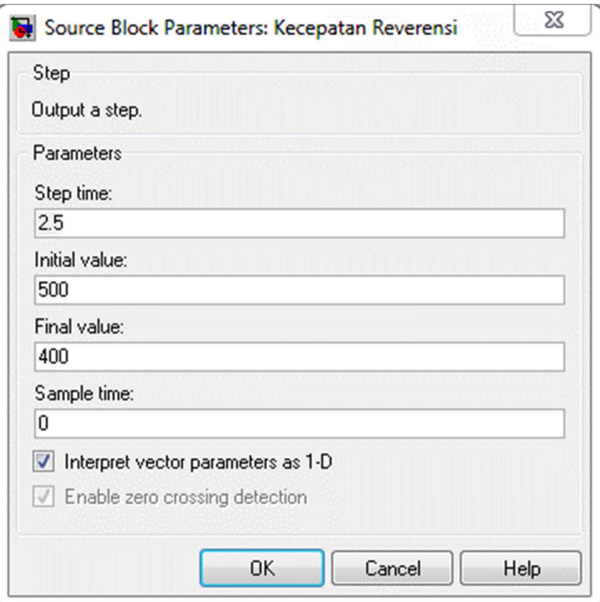

Gambar 7. Parameter pengujian ke 1 pada Kecepatan Referensi

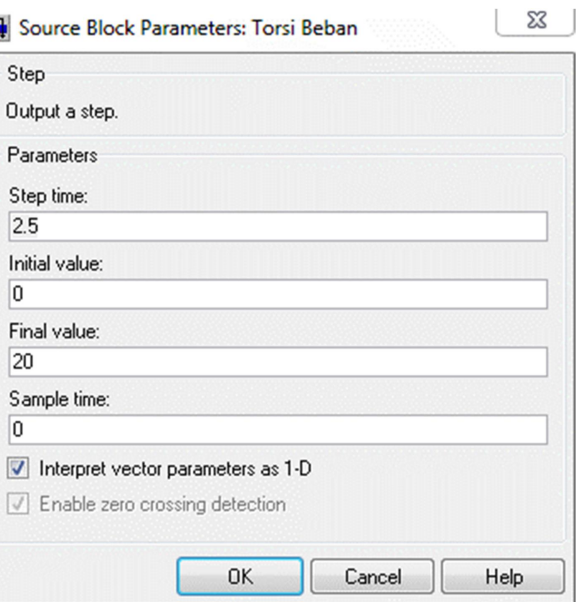

Gambar 8. Parameter pengujian ke 1 pada Torsi Beban

Pada pengujian ke 1, parameter Kecepatan Referensi menggunakan nilai 500 pada initial value, nilai 400 pada final value, dan nilai 2,5 pada step time. Untuk parameter Torsi Beban, menggunakan nilai 0 pada initial value, nilai 20 pada final value, dan nilai 2,5 pada step time.

@ 2021 Satrya Ramadhani, Johan Prasetyo, Firsyaldo Rizky P, M. Haidar Rosyid \& Iradiratu Diah P.K 


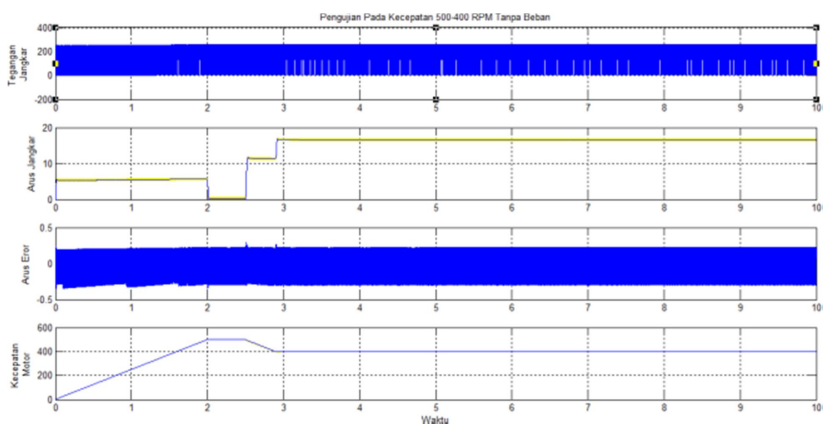

Gambar 9. Pengujian Kecepatan Motor DC 500-400 RPM Tanpa Beban.

Pada gambar tersebut, untuk grafik tegangan jangkar stabil pada nilai $255 \mathrm{v}$. Untuk arus jangkar pada grafik dimulai dari nilai 5,5A konstan selama 2 detik. Setelah 2 detik arus turun dan konstan pada nilai 0,3 A hingga detik ke 2,4s. Pada detik ke 2,5s nilai arus naik, dari $0,3 \mathrm{~A}$ menjadi $11,5 \mathrm{~A}$ konstan selama 0,4 detik. pada detik ke 2,9s, arus naik dan mencapai steady state pada nilai 16,5A. Arus error pada grafik berada pada nilai $0,22 \mathrm{~A}$, namun pada detik ke 0 s, $0,25 \mathrm{~s}$ dan $0,29 \mathrm{~s}$ terjadi lonjakan arus sesaat. Nilai kecepatan nominal sesuai dengan kecepatan referensi (yang diinginkan), yakni pada kecepatan awal 500 RPM lalu turun menjadi 400 RPM pada detik ke 2,5s.

\section{Pengujian 2 Kecepatan Motor DC 500-400 RPM Dengan Beban 10N.m.}

\begin{tabular}{|c|c|}
\hline Source Block Parameters: Kecepatan Reverensi & $\mathfrak{B}$ \\
\hline \multicolumn{2}{|l|}{ Step } \\
\hline \multicolumn{2}{|l|}{ Output a step. } \\
\hline \multicolumn{2}{|l|}{ Parameters } \\
\hline \multicolumn{2}{|l|}{ Step time: } \\
\hline \multicolumn{2}{|l|}{2,5} \\
\hline \multicolumn{2}{|l|}{ Initial value: } \\
\hline \multicolumn{2}{|l|}{500} \\
\hline \multicolumn{2}{|l|}{ Final value: } \\
\hline \multicolumn{2}{|l|}{400} \\
\hline \multicolumn{2}{|l|}{ Sample time: } \\
\hline \multicolumn{2}{|l|}{0} \\
\hline \multicolumn{2}{|l|}{$\nabla$ Interpret vector parameters as $1 \cdot D$} \\
\hline \multicolumn{2}{|l|}{ Enable zero crossing detection } \\
\hline Cancel & Help \\
\hline
\end{tabular}

Gambar 10. Parameter pengujian ke 2 pada Kecepatan Reverensi

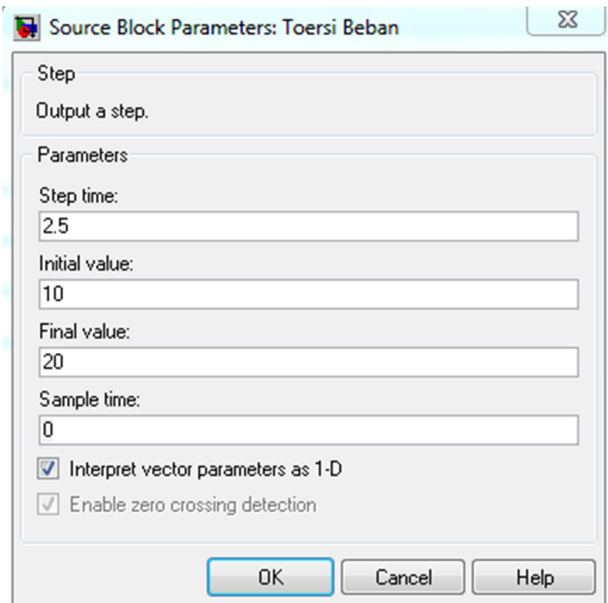

Gambar 11. Parameter pengujian ke 2 pada Torsi Beban

Pada pengujian ke 2, nilai parameter Kecepatan Referensi yang digunakan adalah nilai 500 pada initial value, nilai 400 pada final value, dan nilai 2,5 pada step time. Pada parameter Torsi Beban, menggunakan nilai 10 pada initial value, nilai 20 pada final value, dan nilai 2,5 pada step time

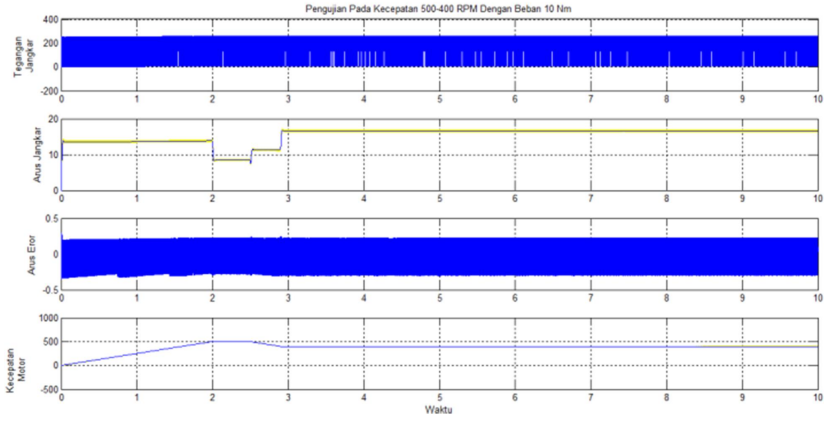

Gambar 12. Pengujian Kecepatan Motor DC 500-400 RPM Dengan Beban 10Nm.

Berdasarkan grafik diatas, tegangan jangkar menunjukkan stabil ketika berada pada nilai $255 \mathrm{v}$. Nilai grafik pada arus jangkar dimulai dari nilai 13,5A konstan selama 2 detik. Pada detik ke 2,1s arus turun dan konstan pada nilai $8,43 \mathrm{~A}$ sampai detik ke 2,4s. Setelah 2,4 detik, arus naik dari 8,43A menjadi 11,5A konstan selama 0,4 detik. Saat grafik berada pada detik ke $2,9 \mathrm{~s}$, arus naik dan mencapai steady state pada nilai 16,59A. Grafik arus error berada pada nilai $0,22 \mathrm{~A}$, namun saat detik ke $0 \mathrm{~s}, 0,25 \mathrm{~s}$ dan 0,29 s terjadi peningkatan arus. Jadi, pada grafik tersebut

menunjukkan nilai kecepatan asli yang sesuai dengan kecepatan referensi yaitu dengan nilai kecepatan awal 500 RPM - 400 RPM yang terjadi pada detik $2,5 \mathrm{~s}$.
Vol 8 No.2@2021 Satrya Ramadhani, Johan Prasetyo, Firsyaldo Rizky P. 2021 M. Haidar Rosyid \& Iradiratu Diah P.K 

Beban 10Nm.

\begin{tabular}{|c|c|}
\hline 1. Source Block Parameters: Kecepatan Reverensi & $\mathfrak{x}$ \\
\hline \multicolumn{2}{|l|}{ Step } \\
\hline \multicolumn{2}{|l|}{ Output a step. } \\
\hline \multicolumn{2}{|l|}{ Parameters } \\
\hline \multicolumn{2}{|l|}{ Step time: } \\
\hline \multicolumn{2}{|l|}{2.5} \\
\hline \multicolumn{2}{|l|}{ Initial value: } \\
\hline \multicolumn{2}{|l|}{600} \\
\hline \multicolumn{2}{|l|}{ Final value: } \\
\hline \multicolumn{2}{|l|}{300} \\
\hline \multicolumn{2}{|l|}{ Sample time: } \\
\hline \multicolumn{2}{|l|}{0} \\
\hline \multicolumn{2}{|l|}{$\nabla$ Interpret vector parameters as $1 . D$} \\
\hline \multicolumn{2}{|l|}{ Enable zero crossing detection } \\
\hline Cancel & Help \\
\hline
\end{tabular}

Gambar 13. Parameter pengujian ke 3 pada Kecepatan Reverensi

Pada pengujian ke 3, untuk parameter Kecepatan Referensi menggunakan nilai 600 pada initial value, nilai 300 pada final value, dan nilai 2,5 pada step time. Nilai parameter Torsi Beban yang digunakan adalah nilai 10 untuk initial value, nilai 20 untuk final value, dan nilai 2,5 untuk step time.

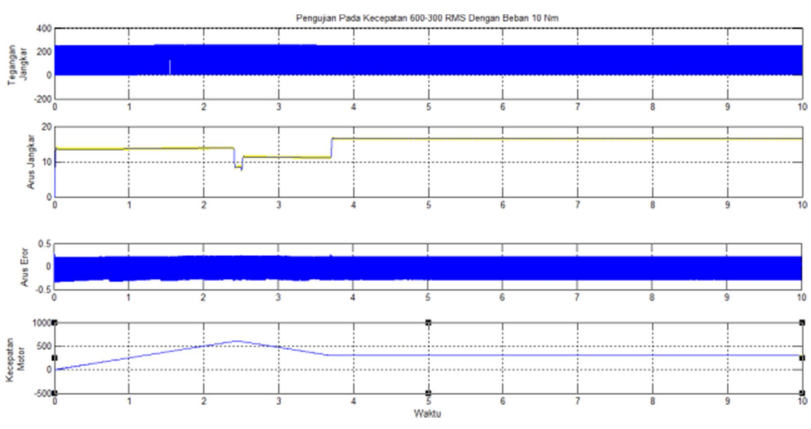

Gambar 14. Pengujian Kecepatan Motor DC 600-300 RPM Dengan Beban $10 \mathrm{Nm}$

Pada grafik tersebut, untuk tegangan jangkar stabil pada nilai 255v. Untuk grafik arus jangkar dimulai dari nilai 13,5A konstan selama 2,35 detik. Setelah 2,35 detik arus mengalami penurunan dan konstan dengan nilai 8,51A hingga detik ke 2,5s. Setelah 2,5 detik arus mengalami kenaikan, dari 8,51A menjadi 11,3A dan konstan selama 1,19 detik. Ketika grafik berada pada detik ke 3,7s, arus mengalami kenaikan lagi dan mencapai kondisi steady state pada nilai 16,59A. Untuk grafik arus eror berada pada nilai $0,22 \mathrm{~A}$, namun pada saat detik ke $0 \mathrm{~s}$,

ISSN 2615-5788 Print (2615-7764)

JURNAL TEKNIK ELEKTRO DAN KOMPUTER TRIAC

Vol 8 No. 2021
$0,25 \mathrm{~s}$ dan $0,37 \mathrm{~s}$ arus eror mengalami kenaikan sesaat. Berdasarkan nilai kecepatan referensi yang sudah dibuat yaitu kecepatan awal 600 RPM - 300 RPM pada detik ke $2,5 \mathrm{~s}$, nilai grafik kecepatan nominal sesuai dengan nilai grafik kecepatan referensi.

E. Pengujian 4 Kecepatan Motor DC 600-300 RPM Dengan Beban 10Nm Pada Step Time Kecepatan Referensi 3 s dan Step Time Torsi Beban 6 s

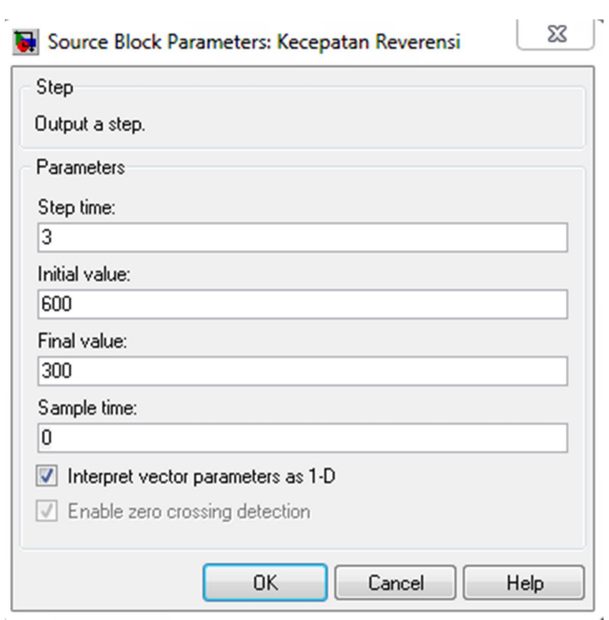

Gambar 15. Parameter pengujian ke 4 pada Kecepatan Reverensi

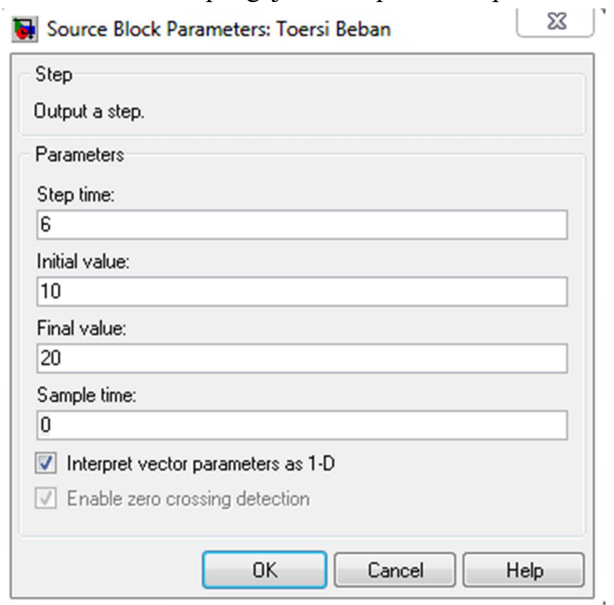

Gambar 16. Parameter pengujian ke 3 pada Torsi Beban

Unruk pengujian 4, nilai parameter Kecepatan Referensi setting dengan nilai 600 pada initial value, nilai 300 untuk final value, dan nilai 2,5 untuk step time. Parameter Torsi Beban yang digunakan adalah nilai 10 untuk initial value, nilai 20 untuk final value, dan nilai 2,5 untuk step time

https://journal.trunojoyo.ac.id/triac 


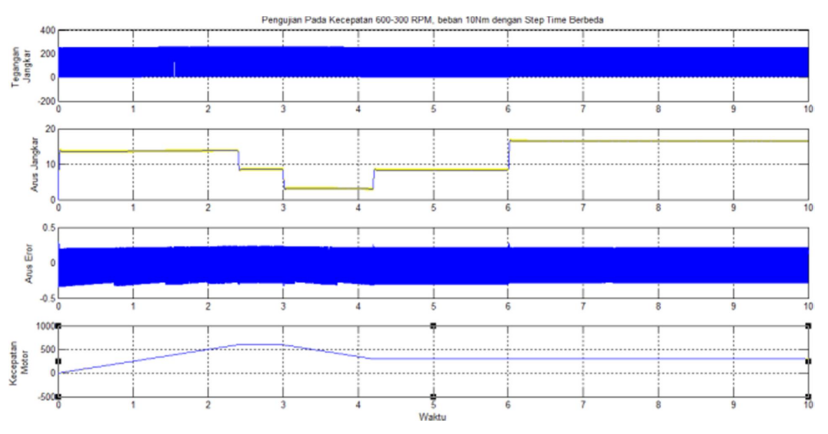

Gambar 17. Pengujian Kecepatan Motor DC 600-300 RPM Dengan Beban 10Nm.

Bedasarkan gambar grafik di atas, untuk grafik pada tegangan jangkar stabil dengan nilai $255 \mathrm{v}$. Untuk grafik arus jangkar dimulai dengan nilai 13,8A konstan selama 2,35 detik. Pada detik ke 2,4s arus turun dan konstan dengan nilai 8,5A lagi, dari nilai 8,5A menjadi 3,2A lalu konstan selama 1,19 detik. Saat detik ke 4,2s arus mengalami kenaikan dari 3,2A menjadi 8,3A lalu konstan sampai detik ke 5,8s. Pada detik ke 6s arus mengalami kenaikan dan mencapai kondisi steady state dengan nilai 16,59A. Nilai grafik arus berada pada 0,22A, namun ketika detik ke $0 \mathrm{~s}, 0,43 \mathrm{~s}$ dan $0,6 \mathrm{~s}$ terjadi peningkatan sesaat pada arus eror. Jadi pada pengujian ini didapatkan nilai nominal yang sesuai dengan kecepatan referensi yaitu kecepatan awal 600 RPM kemudian 300 RPM pada detik ke 3.

Tabel Hasil Parameter Pengujian

\begin{tabular}{|c|c|c|c|c|}
\hline Pengujian & $\begin{array}{c}\text { Tegang } \\
\text { an } \\
\text { Jangkar }\end{array}$ & $\begin{array}{c}\text { Arus } \\
\text { Jangkar } \\
\text { (Steady } \\
\text { State) }\end{array}$ & $\begin{array}{c}\text { Arus } \\
\text { Error }\end{array}$ & $\begin{array}{c}\text { Kecepatan } \\
\text { Motor } \\
\text { (Steady } \\
\text { State) }\end{array}$ \\
\hline 1 & $255 \mathrm{~V}$ & $16,5 \mathrm{~A}$ & $0,22 \mathrm{~A}$ & $400 \mathrm{rpm}$ \\
\hline 2 & $255 \mathrm{~V}$ & $16,5 \mathrm{~A}$ & $0,22 \mathrm{~A}$ & $400 \mathrm{rpm}$ \\
\hline 3 & $255 \mathrm{~V}$ & $18 \mathrm{~A}$ & $0,22 \mathrm{~A}$ & $300 \mathrm{rpm}$ \\
\hline 4 & $255 \mathrm{~V}$ & $18 \mathrm{~A}$ & $0,22 \mathrm{~A}$ & $300 \mathrm{rpm}$ \\
\hline
\end{tabular}

Berdasarkan tabel dapat terlihat bahwa arus steady state selalu sama meskipun keadaan beban yang berbeda dan kecepatan referensi yang berbeda, hal ini dapat dikatakan bahwa metode histerisis mampu menjaga arus konstan pada 16,5 A dan juga dari perbedaan percobaan 2 dan 3 dengan beban berbeda terlihat bahwa hingga detik ke 2,9s. Setelah 2,9s arus mengalami penurunan

\section{F. Tabel Hasil Pengujian} arus histerisis mempunyai tingkat keakurasian yang tinggi dimana

kecepatan referensi hampir sama dengan kecepatan nominal. Dengan ini terlihat bahwa metode histerisis mampu mengontrol kecepatan motor DC Chopper dengan baik sesuai keinginan.

\section{KesimpUlan}

Setelah melakukan penelitian tentang metode histerisis kontrol arus untuk pengaturan kecepatan dan torsi pada motor dc chopper, maka dihasilkan kesimpulan sebagai berikut:

1. Tegangan jangkar yang terdapat pada ke tiga pengujian memiliki nilai yang sama, yakni 254,9v.

2. Tegangan sumber dan tegangan jangkar memiliki nilai yang berbeda. Perbedaan tersebut disebabkan oleh penggunaan buck converter pada sistem.

3. Pada penelitian ini implementasi Metode Hysterisis pada Motor DC Chopper dikatakan valid untuk mengkontrol arus eror, dikarenakan pada pengujian yang telah dilakukan didapatkan arus eror 0,22A atau hampir mendekati 0 .

4. Dengan Metode Hysterisis ini dapat digunakan sebagai alternatif untuk menghasilkan kecepatan yang konstan, meskipun mendapatkan input beban yang variatif.

5. Berdasarkan pengujian yang telah dilakukan, kecepatan nominal dan kecepatan referensi pada Motor DC Chopper, memiliki tingkat ke akurasian yang tinggi.

\section{Daftar Pustaka}

[1] A.K. Mishra, V.K. Tiwari, R. Kumar, "Speed control of dc motor using artificial bee colony optimization technique," IEEE International Conference on Control, Automation, Robotics and Embedded Systems (CARE 2013), Jabalpur, 2013.

[2] Mahmood, O. T. (2018). Speed Reference Tracking for Separately Excited DC Motor Based ANFIS and Hysteresis Current Control Techniques. Engineering and Technology Journal, 36(6 Part A).

[3] Esario, M. I., \& Yuhendri, M. (2020). Kendali Kecepatan Motor DC Menggunakan DC Chopper Satu Kuadran Berbasis Kontroller PI. JTEV (Jurnal Teknik Elektro dan Vokasional), 6(1), 296-305.

[4] Yakob Liklikwatil, Mesin-mesin Listrik untuk D3. Yogyakarta: Deepublish, 2014.

[5] Mihai Albu, Lab no.18 One and Two Quadran ISSN 2615-5788 Print (2615-7764) JURNAL TEKNIK ELEKTRO DAN KOMPUTER TRIAC

\footnotetext{
@ 2021 Satrya Ramadhani, Johan Prasetyo, Firsyaldo Rizky P, M. Haidar Rosyid \& Iradiratu Diah P.K
} 
Choppers. Technical University of lasi: Power Electronics Laboratory. 2018

[6] Bahari, N. B., bin Jidin, A., bin Abdullah, A. R., bin Othman, M. N., \& bin Manap, M. (2012, September). Modeling and simulation of torque hysteresis controller for brushless DC motor drives. In 2012 IEEE Symposium on Industrial Electronics and Applications (pp. 152-155). IEEE.

[7] Esario, Muhamad Ilham, and Muldi Yuhendri. "Kendali Kecepatan Motor DC Menggunakan DC Chopper Satu Kuadran Berbasis Kontroller PI." JTEV (Jurnal Teknik Elektro dan Vokasional) 6.1 (2020): 296-305.

[8] Sandjojo, F. A., Setiawan, I., \& Andromeda, T. (2018). IMPLEMENTASI KONTROL ARUS PADA INVERTER SATU FASA MENGGUNAKAN DSPIC30F4011 DENGAN METODE KONTROL HYSTERESIS. Transient: Jurnal Ilmiah Teknik Elektro, 7(1), 327-333.

[9] Sandhi, Novrian Eka, et al. "METODE PENENTUAN RUGI-RUGI HISTERESIS PADA PENGATURAN MOTOR INDUKSI BERBASIS VECTOR CONTROL." Jurnal Integrasi 12.1 (2020): 13-20.

[10] Putra, Tri Yogi, and Muldi Yuhendri. "Implementasi Hysterisis Current Control Pulse Witdh Modulation (HCCPWM) Untuk Inverter 3 Fasa." JTEIN: Jurnal Teknik Elektro Indonesia 2.1 (2021): 91-97.

Vol 8 No.2@2021 Satrya Ramadhani, Johan Prasetyo, Firsyaldo Rizky P, 2021 M. Haidar Rosyid \& Iradiratu Diah P.K 